\title{
The Effects of Auxins and Cytokinin on Growth and Development of (Musa sp.) Var. “Yangambi” Explants in Tissue Culture
}

\author{
Munguatosha Ngomuo ${ }^{1}$, Emerald Mneney $^{2}$, Patrick Ndakidemi ${ }^{*}$ \\ ${ }^{1}$ School of Life Sciences, Nelson Mandela African Institution of Science and Technology, Arusha, Tanzania; ${ }^{2}$ Mikocheni Agricul- \\ tural Research Institute, Dar es Salaam, Tanzania. \\ Email: ${ }^{*}$ ndakidemipa@gmail.com
}

Received August 12 $2^{\text {th }}, 2013$; revised September 12 $2^{\text {th }}, 2013$; accepted October $21^{\text {st }}, 2013$

Copyright (C) 2013 Munguatosha Ngomuo et al. This is an open access article distributed under the Creative Commons Attribution License, which permits unrestricted use, distribution, and reproduction in any medium, provided the original work is properly cited.

\begin{abstract}
The aim of this study was to investigate the effects of concentration of different growth regulators (auxins and cytokinins) on growth and development of banana shoot tips cultured in vitro. Explants were taken from young suckers of field grown plants of var. "Yangambi". The shoot tips were cultured on MS media supplemented with different concentrations of BAP $(0,2,4,6$ and $8 \mathrm{mg} / \mathrm{l})$ with or without IAA at concentration of $0.34 \mathrm{mg} / \mathrm{l}$. At the rooting phase, the media was supplemented with different concentrations of IBA $(0.1,0.5,1.0,1.5$ and $2.0 \mathrm{mg} / \mathrm{l})$ with or without BAP at concentration of $0.2 \mathrm{mg} / \mathrm{l}$. The results indicated that $6.0 \mathrm{mg} / \mathrm{l}$ BAP significantly increased the number of shoots formed and the interaction of $6 \mathrm{mg} / \mathrm{l} \mathrm{BAP}$ with $0.35 \mathrm{mg} / \mathrm{l}$ IAA significantly increased the fresh weight. For rooting, $2.0 \mathrm{mg} / 1$ IBA was more efficient in number and length of roots produced than all other treatments.
\end{abstract}

Keywords: Bud's Proliferation; Fresh Weight; In-Vitro Rooting; Root Length; Micro Propagation; Shoot Length; Var. "Yangambi"

\section{Introduction}

Growth regulators play a key role for developing a specific mode of growth in the cultured cells or tissues, which may be due to accumulation of specific biochemical contents in them. The single or combination of different hormones in the medium causes maintenance of specific and balanced inorganic and organic contents in the growing tissue. This leads the cells or tissues to develop either into shoots/or roots or even death [1].

In tissue culture, plant growth regulators are important media components in determining the development and developmental pathway of the plant cells. Growth regulators are used in different proportions to break dormancy and enhance shoot formation since it is well demonstrated that the apical dormancy is under control of these growth regulators [2]. The cytokinins and auxins are of importance in in-vitro culture as the later are concerned with root formation, the former is mainly required

\footnotetext{
"Corresponding author.
}

in the media for shoot formation and growth of buds [3]. These growth regulators are required in combination in the media as it is always the manipulation and variation of auxins and cytokinins levels that can successfully change the growth behavior of plant cultures [4].

Cytokinins such as benzyl aminopurine (BAP) and kinetin are known to reduce the apical meristem dominance and induce both axiliary and adventitious shoot formation from meristematic explants in banana [5]. However, the application of higher BAP concentrations inhibits elongation of adventitious meristems and the conversion into complete plants [6].

Auxins and other growth regulators such as gibberellins play important roles in the growth and differentiation of cultured cells and tissues [7,8]. Auxins such as Naphtalene acetic acid (NAA) have been reported to promote plant rooting in vitro $[9,10]$.

The use of cytokinin in plant nutrient media for in-vitro culture depends on plant tissue growth stage and expected end product.

In studies conducted on banana, apical meristems were 
cultured in media of high cytokinin concentration or lower cytokinin at the first stage then transferred to a media with higher cytokinin concentration where the increase in concentration especially BA significantly enhanced buds proliferation [10].

Apart from the influence of genotypes, shoot proliferation rate and elongation are influenced by cytokinin types and their concentration. Adenine-based cytokinins are used in several Musa spp. for in-vitro propagation [11]. N6-benzylaminopurine (BAP) is the most commonly preferred cytokinin [9]. The others are isopentyladenine (2-ip), zeatin and kinetin [12]. The concentration of exogenous cytokinin appears to be the main factor affecting multiplication.

Many other studies have reported the use of auxins and cytokinin in tissue culture. Gubbuk and Pekmzci (2004) [11] reported that moderate concentrations of cytokinins increased the shoot proliferation rate, but very high concentrations decreased multiplication and especially depressed shoot elongation. Also they reported higher shoot proliferation and elongation with Thidiazuron (TDZ) than with BAP. However, BAP above $20 \mu \mathrm{M}$ and TDZ over $2 \mu \mathrm{M}$ decreased shoot elongation. The use of TDZ is known to inhibit shoot elongation. In another study, it was found that TDZ at $0.91 \mu \mathrm{M}$ induced the largest number of shoots, but at higher concentration of TDZ $(9.1 \mu \mathrm{M})$, elongation of shoots was inhibited and clumps of small globular buds appeared at the base of shoots [13].

In a study on effects of auxin/cytokinin combination on shoot proliferation on banana cultivars, Arinaitwe et al. reported that incorporation of a strong auxin in the media suppressed the shoot proliferation rates of the banana cultivars [15]. On media modified with low cytokinin/auxin ratios, for example 16.8/1.0 and 16.8/1.2 ZN/NAA combinations, the East African Highland banana (AAA-EA) cultivars showed single shoot development and callus induction due to apical dominance resulted from increased level of auxin concentration [15]. In another study, Buah et al. [15] demonstrated that differences exist in the relative strengths of different cytokinin types in inducing shoots. This differential ability of different hormones in inducing shoots in vitro may be attributed to factors such as stability, mobility and the rate of conjugation and oxidation of hormones.

The concentration and combination of auxins and cytokinins in the nutrient mediums is an important factor which determines successful plant regeneration [16]. Thus for efficient in-vitro propagation of banana the study of optimum combination of cytokinins and auxins and their interaction in a tissue culture medium for a specific cultivar is necessary.

\section{Materials and Methods}

\subsection{Plant Materials and Sterilization}

Young suckers of Musa var. "Yangambi" were collected from a healthy true to type mother plants. After removing the leaves and the roots, the suckers were thoroughly washed with tape water and liquid soap to remove adhering soil. The suckers were trimmed to size by removing layers of the developing leaves. Then the suckers were rinsed with clean tape water and soaked in $1 \mathrm{~g} / 1$ ascorbic acid for one hour before transfer to laminar flow. The shoot apices explants were sequentially treated with $70 \%$ alcohol for 30 seconds, then treated with $100 \%(\mathrm{v} / \mathrm{v})$ hypochlorite (the active ingredient was $3.85 \%$ sodium hypochlorite) mixed with few drops of Tween 20 for one hour in order to sterilize the surface. This was then followed with treatment of $50 \%(\mathrm{v} / \mathrm{v})$ hypochlorite of the same active ingredient for 30 minutes. The explants were further trimmed to remove the remaining hypochlorite and rinsed with sterile distilled water before initiation.

\subsection{Culture Conditions and Media for Buds Proliferation}

The explants were placed in culture vessels containing 20 mls of culture media containing MS basal salts supplemented with $20 \mathrm{~g} / \mathrm{l}$ sucrose, vitamins; glycine $2 \mathrm{~g} / \mathrm{l}$, pyridoxine $0.5 \mathrm{~g} / \mathrm{l}$, Nicotinic acid $0.5 \mathrm{~g} / \mathrm{l}$, Thiamine 0.1 $\mathrm{g} / 1$ and Myo inositol at $0.1 \mathrm{~g} / \mathrm{l}$. The media was also supplemented with different concentrations of BAP and IAA as shown in (Table 1) and solidified with $4.5 \mathrm{~g} / \mathrm{l}$ of agar. The $\mathrm{pH}$ was adjusted to 5.8 prior to autoclaving at $121^{\circ} \mathrm{C}$ for $15 \mathrm{~min}$.

\subsection{Roots Initiation Media}

Good established shoots were transferred to root initiation media. This media consisted of MS basal salts with

Table 1. Different concentrations of BAP and IAA used for buds proliferation.

\begin{tabular}{cc}
\hline Treatments & Concentration (mg/l) \\
\hline MS + BAP & 0 \\
MS + BAP & 2 \\
MS + BAP & 4 \\
MS + BAP & 6 \\
MS + BAP & 8 \\
MS + (BAP + IAA) & $0+0.35$ \\
MS + (BAP + IAA) & $2+0.35$ \\
MS + (BAP + IAA) & $4+0.35$ \\
MS + (BAP + IAA) & $6+0.35$ \\
MS + (BAP + IAA) & $8+0.35$ \\
\hline
\end{tabular}


$20 \mathrm{~g} / 1$ sucrose, vitamins glycine $2 \mathrm{~g} / \mathrm{l}$, pyridoxine $0.5 \mathrm{~g} / \mathrm{l}$, Nicotinic acid $0.5 \mathrm{~g} / \mathrm{l}$, Thiamine $0.1 \mathrm{~g} / \mathrm{l}$ and Myo inositol at $0.1 \mathrm{~g} / \mathrm{l}$. The media also contained $0.8 \mathrm{~g} / \mathrm{l}$ of activated charcoal (AC) to mimic the soil environment. It was supplemented with different concentrations of auxin as treatments for rooting; IBA with or without BAP as shown in (Table 2) and solidified with $4.5 \mathrm{~g} / 1$ of agar. Each treatment was replicated five times and one explant was cultured in each culture bottle. The $\mathrm{pH}$ of the media was adjusted to 5.8 before addition of agar. The media were autoclaved at $121^{\circ} \mathrm{C}$ and $1.05 \mathrm{~kg} / \mathrm{cm}^{3}$ for 15 minutes. The cultures were incubated at $25^{\circ} \mathrm{C} \pm 1{ }^{\circ} \mathrm{C}$ and 16 and 8 hrs light and darkness respectively.

\subsection{Data Collection and Analysis}

After four weeks the following parameters were measured; fresh weight $(\mathrm{g})$, number of shoots, height $(\mathrm{cm})$, roots length $(\mathrm{cm})$ and number of roots. The data collected were analyzed for statistical significance using analysis of variance (ANOVA). These computations were done by using a statistical software program STATISTICA version 2013 (StatSoft Inc., Tulsa, OK, USA). Fisher least significance was used to compare means at $p=0.05$ level of significance.

\section{Results and Discussion}

\subsection{The Effect of BAP Concentration on Bud Proliferation Rate}

The findings of this study demonstrated the effects of cytokoinins on shoots formation and multiplication. In this experiment, the use of BAP alone or in combination with IAA had no significant ( $\mathrm{p} \leq 0.05$ ) effect on buds proliferation (Table 3). However, different concentrations regimes of BAP with and without IAA had significant effect on the number of buds produced as well as

Table 2. Different concentrations of IBA and BAP used for rooting.

\begin{tabular}{cc}
\hline Treatments & Concentration (mg/l) \\
\hline MS + IBA & 0 \\
MS + IBA & 0.5 \\
MS + IBA & 1.0 \\
MS + IBA & 1.5 \\
MS + IBA & 2.0 \\
MS + (IBA + BAP) & $0+0.2$ \\
MS + (IBA + BAP) & $0.5+0.2$ \\
MS + (IBA + BAP) & $1.0+0.2$ \\
MS + (IBA + BAP) & $1.5+0.2$ \\
MS + (IBA + BAP) & $2.0+0.2$ \\
\hline
\end{tabular}

fresh weight increase in buds produced. It was observed that the number of buds produced increased with increase in concentration. A significantly $(\mathrm{p} \leq 0.001)$ highest number of buds were observed when $6 \mathrm{mg} / 1$ was used (Table 3). Slightly increase in number of buds was also observed in other treatments with low concentrations compared with the control. Bhosale et al. [17], in a study on in vitro shoot multiplication of different species of banana similarly reported increased average number of shoots produced at nearly same level of BAP $(7 \mathrm{mg} / \mathrm{l})$. In another study, Sajid et al. [18], found that presence of cytokinin in the media did not only determined regeneration response of banana meristem cultures but also affected the mode of regeneration. The initial response of explants to shoot formation due to addition of cytokinin is mediated by an increase in the cytosolic calcium concentration which is promoted by its high uptake from the media. This affects cytoskeleton and regulates exocytosis [19].

Other studies by $[12,20,21]$ observed that $5 \mathrm{mg} / 1$ BAP was the most efficient concentration for in vitro bud proliferation of many banana cultivars. In a review on banana cell and tissue culture, Strosse et al. [22] indicated that for multiplication of propagules, a medium containing a range of concentration $0.1-20 \mathrm{mg} /$ of BA is added to the media.

In this study, higher concentration beyond $6 \mathrm{mg} / \mathrm{did}$ not enhance fresh weight or number of buds produced. At concentration of $8 \mathrm{mg} / \mathrm{l}$ the number of buds produced was less compared with concentrations of $4 \mathrm{mg} / \mathrm{l}$ and 6 $\mathrm{mg} / \mathrm{l}$. Higher concentrations of cytokinin tend to have an adverse effect on the multiplication rate and morphology of the culture [5,22].

Generally, this study indicates that increasing concentration of BAP for this particular variety enhanced the fresh weight and buds formations. Addition of $6 \mathrm{mg} / \mathrm{l}$ to the growth media showed best results compared with all other treatments (Figure 1). This seems to be the optimal concentration for this variety. In vitro buds proliferation of banana is reported to be cultivar dependent [23]. Also Strosse et al. [24] indicated that the rate of shoots multiplication depends both on the cytokinin concentration and the genotype of banana.

\subsection{The Effect of BAP and IAA Concentration on Fresh Weight and Shoot Length}

Generally, the results indicated that like in buds proliferation, fresh weight increase was significantly $(p \leq 0.01)$ better at higher concentration $(6 \mathrm{mg} / \mathrm{l})$ (Table 3). Treatments supplied with $6 \mathrm{mg} / \mathrm{l}$ showed best results in terms of fresh weight followed by treatments with $2 \mathrm{mg} / \mathrm{l}$ and 8 $\mathrm{mg} / \mathrm{l}$. Other studies reported that combinations of BAP with IAA or IBA were more efficient for in vitro multi- 
(Musa sp.) Var. "Yangambi” Explants in Tissue Culture

Table 3. Effect of BAP concentration with and without IAA on the number of buds formed, fresh weight and shoot length.

\begin{tabular}{|c|c|c|c|}
\hline \multirow[b]{2}{*}{ Treatment } & \multicolumn{3}{|c|}{ Growth Parameters } \\
\hline & Number of Buds & Fresh Weight & Shoot Length \\
\hline \multicolumn{4}{|l|}{ Growth Regulators } \\
\hline BAP & $5.42 \pm 0.47 \mathrm{a}$ & $3.26 \pm 0.23 \mathrm{a}$ & $3.66 \pm 0.30 \mathrm{a}$ \\
\hline $\mathrm{BAP}+\mathrm{IAA}$ & $6.06 \pm 0.56 \mathrm{a}$ & $3.54 \pm 0.28 \mathrm{a}$ & $3.79 \pm 0.28 \mathrm{a}$ \\
\hline \multicolumn{4}{|l|}{ Concentration } \\
\hline $0 \mathrm{mg} / 1$ & $1.45 \pm 0.21 \mathrm{e}$ & $2.40 \pm 0.27 b$ & $3.09 \pm 0.39 \mathrm{a}$ \\
\hline $2 \mathrm{mg} / 1$ & $4.45 \pm 0.61 \mathrm{~d}$ & $3.70 \pm 0.38 \mathrm{ab}$ & $3.23 \pm 0.35 \mathrm{a}$ \\
\hline $4 \mathrm{mg} / 1$ & $7.30 \pm 0.54 \mathrm{bcd}$ & $3.14 \pm 0.24 b$ & $4.11 \pm 0.33 \mathrm{a}$ \\
\hline $6 \mathrm{mg} / 1$ & $9.55 \pm 0.66 \mathrm{ab}$ & $4.19 \pm 0.76 \mathrm{ab}$ & $4.45 \pm 0.65 \mathrm{a}$ \\
\hline $8 \mathrm{mg} / 1$ & $5.95 \pm 0.61 \mathrm{~cd}$ & $3.56 \pm 0.39 \mathrm{ab}$ & $3.82 \pm 0.47 \mathrm{a}$ \\
\hline \multicolumn{4}{|c|}{ 2-Way ANOVA (F - Statistic) } \\
\hline Growth Regulators & $1.66^{\mathrm{ns}}$ & $0.70^{\mathrm{ns}}$ & $0.11^{\mathrm{ns}}$ \\
\hline Concentration & $29.99^{* * *}$ & $3.17^{* *}$ & $1.63^{\mathrm{ns}}$ \\
\hline Growth Regul $*$ Conc & $0.56^{\mathrm{ns}}$ & $2.66^{* *}$ & $0.41^{\mathrm{ns}}$ \\
\hline
\end{tabular}

${ }^{* *} \mathrm{p} \leq 0.01 ;{ }^{* * *} 0.001$. Values (Mean $\pm \mathrm{SE}$ ) Followed by dissimilar letter(s) in a column are significantly different by Least Significant Difference test at $\mathrm{P}=0.05$. ns $=$ non-significant.

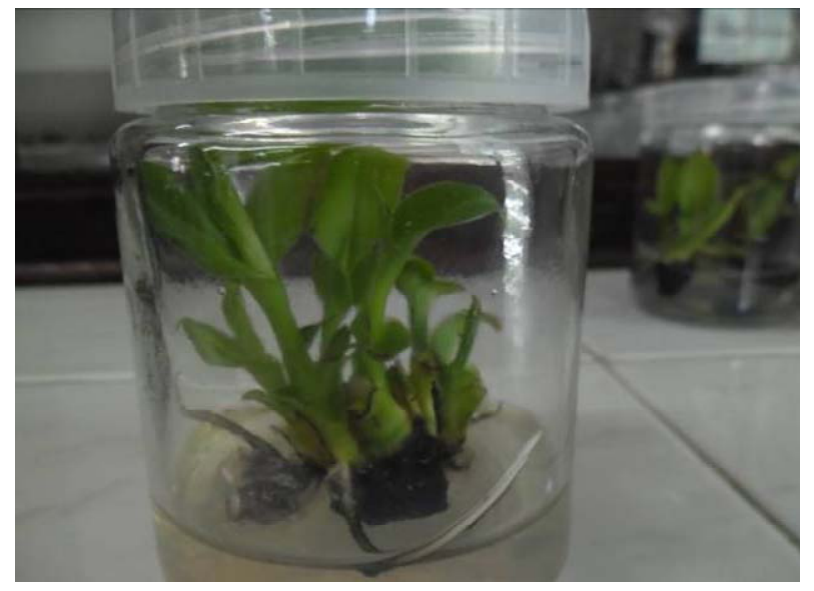

Figure 1. Some of banana shoots developed in vitro at concentration of $6 \mathrm{mg} / \mathrm{l} \mathrm{BAP}$ and $0.35 \mathrm{mg} / \mathrm{IAA}$.

plication of bananas and plantains [24]. As reported earlier, increase in fresh weight may also be attributed to increased cytosolic calcium concentration resulting from enhanced uptake from the media due to the use of higher amount of BAP.

Interactive effect of BAP and IAA was also observed in fresh weight (Figure 2). The media with $6 \mathrm{mg} / \mathrm{l}$ of BAP in combination with $0.35 \mathrm{mg} / 1$ IAA, significantly ( $p$ $\leq 0.01$ ) resulted in high fresh weight as compared with other treatments (Table 3). The interactive effect of cytokinin and auxin in enhancing growth of tissue

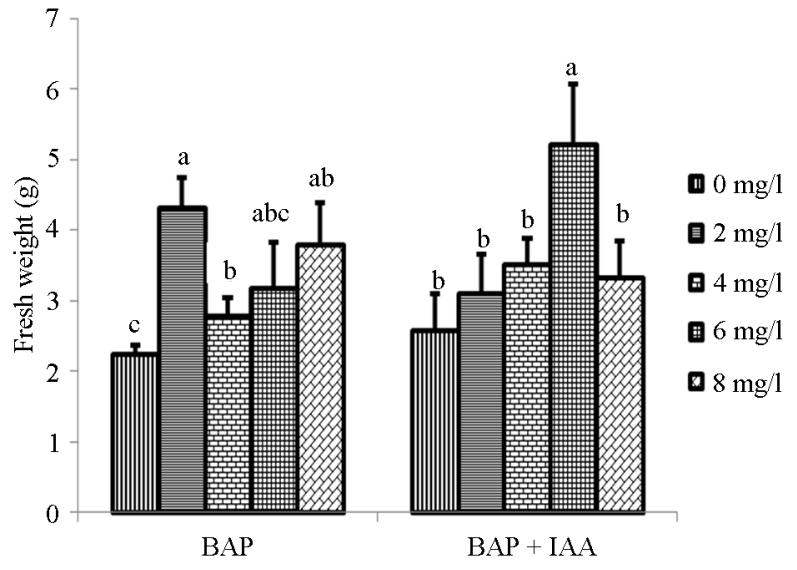

Figure 2. Interactive effect of BAP with IAA on fresh weight of buds produced.

cultured banana is also reported by Hussein [10], whereby supplementing NAA to increasing concentration of BA (from 0.2 to $0.4 \mathrm{mg} / \mathrm{l}$ ) resulted in higher fresh weight and plant height.

In terms of shoot length increase, there was no significant difference across all the treatments, though slight increases were observed in the treatments with relatively high concentration. These findings did not agree with the results of Al-Amin et al. [25], where the MS media supplemented with BAP and NAA in their study showed different results for increasing shoot length 
which was significantly influenced by different concentration of these hormones.

\subsection{The Effect of IBA and BAP Concentration on the Number of Roots per Explant Produced in Vitro}

In this study, there was no significant difference between MS media supplemented with IBA alone and media supplemented with IBA and BAP in terms of number of roots produced per explant (Table 4). However, significant $(p \leq 0.001)$ increase in number of roots produced was observed with increased concentration. The concentration of $2.0 \mathrm{mg} / 1$ exhibited superiority over all other treatments in terms of number of roots produced (6.1 roots per explant) (Figure 3(a)). This was followed by concentration of $1.5 \mathrm{mg} / \mathrm{l}$ while the concentrations of 1.0 $\mathrm{mg} / \mathrm{l}$ and $0.5 \mathrm{mg} / \mathrm{l}$ statistically produced same number of roots per explant. In vitro rooting of banana can be induced by transferring the explants to the basal media alone [26,27]. Gubbuk and Pekmezci [11], reported that activated charcoal was added to the media in replacement of auxins such as IAA or IBA. However, auxins are known to induce quick and further roots initiation [9]. Vuylsteke and De Langhe [12] found that optimal concentration for IBA was $1 \mu \mathrm{M}(\approx 0.2 \mathrm{mg} / \mathrm{l})$ for banana cultivars they were testing. Due to cultivar dependence of response to growth regulators of banana, each cultivar responds differently to similar concentration of growth regulators. In terms of rooting, our experiment indicated

Table 4. Effect of IBA concentration with and without BAP on the number of roots formed and average root length.

\begin{tabular}{ccc}
\hline & \multicolumn{2}{c}{ Growth Parameter } \\
\hline Treatment & Number of roots & Average root length \\
\hline Growth Regulators & & \\
IBA & $3.4 \pm 0.34 \mathrm{a}$ & $5.0 \pm 0.34 \mathrm{a}$ \\
IBA + BAP & $3.9 \pm 0.45 \mathrm{a}$ & $5.4 \pm 0.55 \mathrm{a}$ \\
Concentrations & & \\
0 mg/l & $2.3 \pm 0.47 \mathrm{c}$ & $3.0 \pm 0.75 \mathrm{~d}$ \\
$0.5 \mathrm{mg} / 1$ & $2.9 \pm 0.40 \mathrm{bc}$ & $4.0 \pm 0.71 \mathrm{~cd}$ \\
$1.0 \mathrm{mg} / 1$ & $2.9 \pm 0.52 \mathrm{bc}$ & $5.0 \pm 0.67 \mathrm{bc}$ \\
$1.5 \mathrm{mg} / 1$ & $4.1 \pm 0.48 \mathrm{~b}$ & $6.0 \pm 0.58 \mathrm{~b}$ \\
$2.0 \mathrm{mg} / 1$ & $6.1 \pm 0.52 \mathrm{a}$ & $8.0 \pm 0.61 \mathrm{a}$ \\
2-Way ANOVA & & \\
(F-Statistic) & $1.09^{\mathrm{ns}}$ & $0.46^{\mathrm{ns}}$ \\
Growth regulators & $10.35^{* * *}$ & $8.59^{* * *}$ \\
Concentrations & $1.68^{\mathrm{ns}}$ & $0.42^{\mathrm{ns}}$ \\
\hline Growth regulators*Conc &
\end{tabular}

${ }^{* * *} 0.001$. Values (Mean $\pm \mathrm{SE}$ ) Followed by dissimilar letter(s) in a column are significantly different by Least Significant Difference test at $p=0.05$. ${ }^{\text {ns }}$ $=$ non-significant.

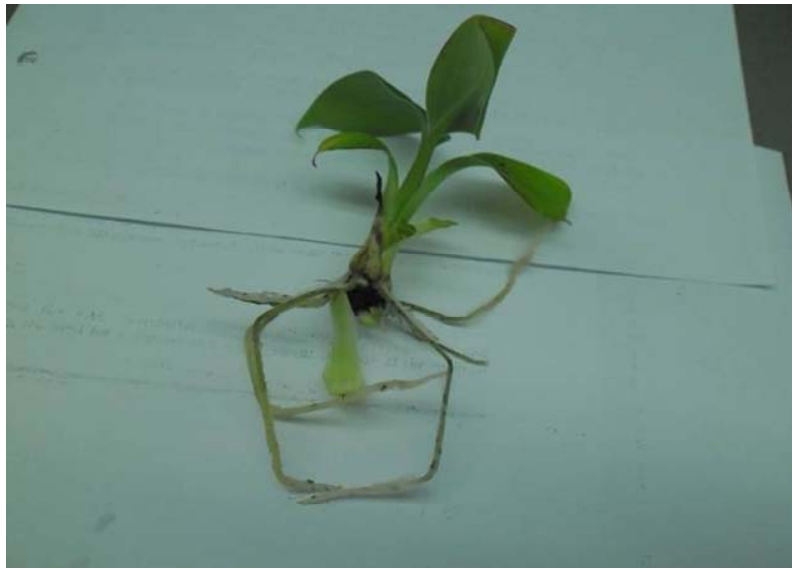

(a)

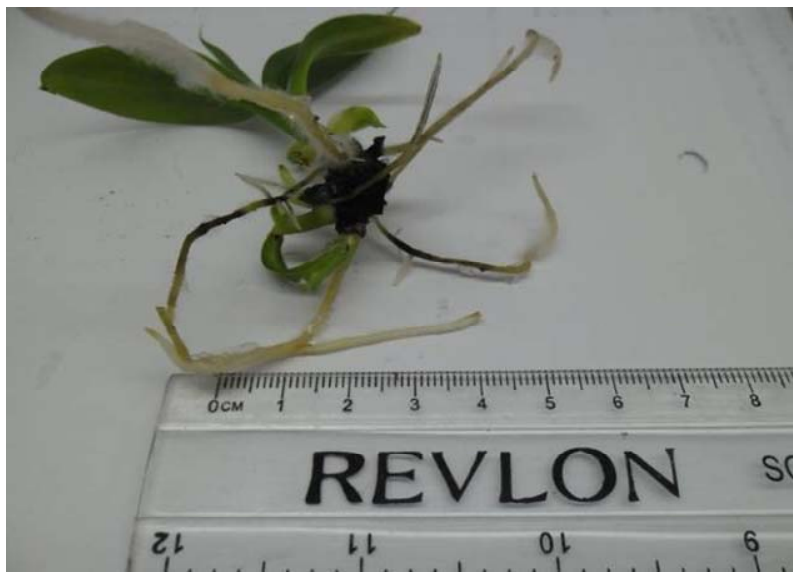

(b)

Figure 3. (a) Some of the explants with the roots produced in vitro at $(2.0 \mathrm{mg} / \mathrm{l} \mathrm{IBA}$ and $0.2 \mathrm{mg} / \mathrm{l} \mathrm{BAP} \mathrm{(b)} \mathrm{Measurement}$ of root length.

that better response to roots initiation of this variety was $2 \mathrm{mg} / \mathrm{l}$.

\subsection{The Effect of IBA and BAP Concentrations on the Length of Roots Produced in Vitro}

Root length varied with different concentrations of IBA and BAP (Table 4). The results indicated that there were increasing trend of root length with increasing concentration. The highest root length was observed in the treatment with concentration of $2 \mathrm{mg} / \mathrm{l}$, where the number of roots produced per explant was 8.0. This was followed by treatment with concentration of $1.5 \mathrm{mg} / \mathrm{l}$ which produced 6.0 roots per explant.

Generally, this trend showed that auxin was essential for quick induction of banana roots in vitro as compared with the control treatment. The necessity of using auxins for roots induction in banana tissue culture is also reported by Raut and Lokhande [28].

Rahman et al. (2013) in their study indicated that 
highest root length of $3.69 \mathrm{~cm}$ was achieved under 1.0 $\mathrm{mg} / \mathrm{l}$ IBA for excised shoots of banana [29]. This may be due to genotype of their cultivar and the relatively low concentration of IBA used, given that the experiment was conducted for six weeks.

In our study, it was evident that $2.0 \mathrm{mg} / \mathrm{l}$ can increase the average root length within short time and reduce the costs associated with tissue culture. This may have a positive influence on the survival of the explants.

\section{Conclusions}

The optimum concentration of BAP for buds proliferation of this variety (Yangambi) was $6 \mathrm{mg} / \mathrm{l}$ as reflected by increased number of buds and fresh weight. The use of BAP in combination with IAA (BAP * IAA) was found to enhance fresh weight at concentration of $6 \mathrm{mg} / \mathrm{l}$ : $0.35 \mathrm{mg} / 1 \mathrm{respectively.} \mathrm{Therefore,} \mathrm{due} \mathrm{to} \mathrm{the} \mathrm{genotype}$ specificity on response of many banana cultivars to tissue culture media, it is recommended that this concentration be used for in vitro propagation of this variety.

As for rooting, supplementing a media for tissue culture of banana variety "Yangambi" with $2.0 \mathrm{mg} / \mathrm{l}$ of IBA increased the number and length of roots formed and reduce the time required to wait for roots to be formed in basal media or media with activated charcoal.

\section{Acknowledgements}

This study was funded by the Nelson Mandela African Institute of Science and Technology through research funds from Commission for Science and Technology $(\mathrm{COSTECH})$ in Tanzania.

\section{REFERENCES}

[1] Ikram-ul-Haq and M. U. Dahot, "Morpho-Physiological Aspects of Micro-Propagating Banana under Different Hormonal Conditions," Asian Journal of Plant Sciences, Vol. 6, No. 3, 2007, pp. 496-501. http://dx.doi.org/10.3923/ajps.2007.496.501

[2] P. Madhulatha, M. Anbalagan, S. Jayachandran and N. Sakthivel, "Influence of Liquid Pulse Treatment with Growth Regulators on in Vitro Propagation of Banana (Musa spp. AAA)," Plant Cell Tissue Organ Culture, Vol. 76, No. 2, 2004, pp. 189-192.

[3] J. North, P. Ndakidemi and C. Laubscher, "Effects of Antioxidants, Plant Growth Regulators and Wounding on Phenolic Compound Excretion during Micropropagation of Strelitzia reginae," International Journal of the Physical Sciences, Vol. 7, No. 4, 2012, pp. 638-646. http://dx.doi.org/10.5897/IJPS11.786

[4] R. A. Dixon and R. A. Gonzales, "Plant Cell Culture: A Practical Approach," 2nd Edition, Oxford University Press, Oxford, 1994.

[5] N. Jafari, R. Y. Othman and N. Khalid, "Effect of Ben- zylaminopurine (BAP) Pulsing on in Vitro Shoot Multiplication of Musa acuminata (Banana) cv. Berangan," African Journal of Biotechnology, Vol. 10, No. 13, 2011, pp. 2446-2450.

[6] C. M. Buising, R. C. Shoemaker and R. M. Benbow, "Early Events of Multiple Bud Formation and Shoot Development in Soybean Embryonic Axes Treated with the Cytokinin, 6-Benzylaminopurine," American Journal of Botany, Vol. 81, No. 1, 1994, pp. 1435-1448. http://dx.doi.org/10.2307/2445317

[7] K. S. Alexandrova, P. D. Denchev and B. Y. Conger, "Micro Propagation of Switchgrass by Node Culture," Crop Science, Vol. 36, No. 6, 1996, pp. 1709-1711. http://dx.doi.org/10.2135/cropsci1996.0011183X0036000 $\underline{60049 x}$

[8] S. Bohidar, M. Thirunavoukkarasu and T. V. Roa, "Effect of Plant Growth Regulators on in Vitro Micro Propagation of 'Garden Rue' (R. graveolens L.)," International Journal of Integrated Biology, Vol. 3, No. 1, 2008, pp. 36-43.

[9] D. Vuylsteke, "Shoot-Tip Culture for the Propagation, Conservation and Exchange of Musa germplasm," IBPGR, Rome, 1989.

[10] N. Hussein, "Effects of Nutrient Media Constituents on Growth and Development of Banana (Musa spp.) Shoot Tips Cultured in Vitro," African Journal of Biotechnology, Vol. 11, No. 37, 2012, pp. 9001-9006.

[11] H. Gubbuk and M. Pekmezci, "In Vitro Propagation of Some New Banana Types (Musa spp.)," Turkish Journal of Agriculture and Forestry, Vol. 28, No. 5, 2004, pp. 355-361.

[12] D. Vuylsteke and E. Lanhe, "Feasibility of in Vitro Propagation of Bananas and Plantains," Tropical Agriculture (Trinidad), Vol. 62, No. 20, 1985, pp. 323-328.

[13] S. Shirani, F. Mahdavi and M. Maziah, "Morphological Abnormality among Regenerated Shoots of Banana and Plantain (Musa spp.) after in Vitro Multiplication with TDZ and BAP from Excised Shoot Tips," African Journal of Biotechnology, Vol. 8, No. 21, 2011, pp. 57555761.

[14] G. Arinaitwe, P. R. Rubaihayo and M. J. S. Magambo, "Effects of Auxin/Cytokinin Combinations on Shoot Proliferation in Banana Cultivars," African Crop Science Journal, Vol. 7, No. 4, 1999, pp. 605-611. http://dx.doi.org/10.4314/acsj.v7i4.27755

[15] J. N. Buah, E. Danso, K. J. Taah, E. A. Abole, E. A. Bediako, J. Asiedu and R. Baidoo, "The Effects of Different Concentrations Cytokinins on the in Vitro Multiplication of Plantain (Musa sp.)," Biotechnology, Vol. 9, No. 3, 2010, pp. 343-347.

http://dx.doi.org/10.3923/biotech.2010.343.347

[16] J. North, P. Ndakidemi and C. P. Laubscher, "The Potential of Developing an in Vitro Method for Propagating Strelitziaceae," African Journal Biotechnology, Vol. 9, No. 45, 2010, pp. 7583-7588.

[17] U. Bhosale, S. Dubhashi, N. Mali and H. Rathod, "In Vitro Shoot Multiplication in Different Species of Banana," Asian Journal of Plant Science and Research, Vol. 1 No. 


$$
\text { 3, 2011, pp. 23-27. }
$$

[18] A. A. A. Sajid, N. H. Naveed, A. Majid, A. Saleem, A. U. Khan, F. I. Jafery and S. Naz, "Initiation, Proliferation and Development of Micro-Propagation System for Mass Scale Production of Banana through Meristem Culture," African Journal of Biotechnology, Vol. 10, No. 70, 2011, pp. 15731-15738.

[19] A. Hagar, G. Debus, H. G. Edil, H. Strosky and R. Serrano, "Auxin Induces Exocytosis and the Rapid Synthesis of a High Turnover Pool of Plasma Membrane $\mathrm{H}^{+}$-APTase," Planta, Vol. 185, No. 4, 1991, pp. 527-537.

[20] L. Venkatachalam, R. V. Sreedhar and N. Bhagyalakshmi, "Micro Propagation in Banana Using High Levels Does Not Involve Any Genetic Change as Revealed by RAPD and ISSR Markers," Plant Growth Regulation, Vol. 51, No. 3, 2007, pp. 192-205. http://dx.doi.org/10.1007/s10725-006-9154-y

[21] M. W. Bairu, W. A. Strik, K. Dolezal and J. V. Staden, "The Role of Topolins in Micro Propagation and Somaclonal Variation of Banana Cultivars 'Williums' and 'Grand Naine' (Musa spp. AAA)," Plant Cell, Tissue and Organ Culture, Vol. 95, No. 3, 2008, pp. 373-379. http://dx.doi.org/10.1007/s11240-008-9451-4

[22] H. Strosse, I. Van den Houwe and B. Panis, "Banana Cell and Tissue Culture Review," Science Publishers, Inc., Gainesville, 2004.

[23] G. Arinaitwe, P. R. Rubaihayo and M. J. S. Magambo, "Proliferation Rate Effects of Cytokinins on Banana
(Musa spp.) Cultivars," Scientia Horticulturae, Vol. 86, No. 1, 2000, pp. 13-21. http://dx.doi.org/10.1016/S0304-4238(00)00124-2

[24] D. Dhed'a, F. Dumortier, B. Panis, D. Vuylsteke and E. De Langhe, "Plant Regeneration in Cell Suspension Cultures of Cooking Banana 'Bluggoe' Cultivar (Musa spp. ABB Group)," Fruits, Vol. 46, No. 2, 1991, pp. 125-135.

[25] M. D. Al-Amin, M. R. Karim, M. R. Amin, S. Rahman and A. N. M Manun, "In Vitro Micro Propagation of Banana," Bangladesh Journal of Agriculture Research, Vol. 34, No. 4, 2009, pp. 645-659.

[26] R. L. Jarret, W. Rodriguez and R. Fernandez, "Evaluation, Tissue Culture Propagation and Dissemination of 'Saba' and 'Pelipita' Plantains in Costa Rica," Scientia Horticulturae, Vol. 25, No. 2, 1985, pp. 137-147. http://dx.doi.org/10.1016/0304-4238(85)90085-8

[27] S. S. Cronauer and A. D. Krikorian, "Multiplication of Musa from Excised Stem Tips," Annals of Botany, Vol. 53, No. 3, 1984, pp. 321-328.

[28] R. S. Raut and V. E. Lokhande, "Propagation of Plantain through Meristem Culture," Annals of Plant Physiology, Vol. 3, No. 2, 1989, pp. 256-260.

[29] S. Rahman, N. Biswas, M. M. Hassan, M. G. Ahmed, A. Mamun, M. R. Islam, M. Moniruzzaman and M. E. Haque, "Micro Propagation of Banana (Musa sp.) cv. Agnishwar by in Vitro Shoot Tip Culture," International Research Journal of Biotechnology, Vol. 4, No. 4, 2013, pp. 83-88. 